\title{
The Impact of Forest Conservation on Agricultural Land Use Change and Alternatives for Livelihood Sustainability in Ngongbaa Community, North West Cameroon
}

\author{
Kongnyuy Anastasia Kininla", Ndi Roland Akoh \\ University of Yaounde I, Yaounde - Cameroon
}

DOI: $10.36348 /$ sjhss.2020.v05i08.002

| Received: 15.07.2020 | Accepted: 27.07.2020 | Published: 14.08.2020

*Corresponding author: Kongnyuy Anastasia Kininla

\section{Abstract}

Forest conservation is the practice of planting and maintaining forested areas for the benefit and sustainability of future generations. Forest conservation involves the upkeep of the natural resources within a forest that are beneficial to both humans and the environment. This paper attempts an insightful look at the contributions of forest conservation in Ngongbaa on agricultural land use change and how it affects crop production and subsequently the population. This approach considers forest as an important asset to the entire rural community and forest conservation as an obstacle to their development. The methodology used consisted of data collection through interviews, questionnaire administration, participant observation and on-the-spot appraisal. The findings revealed that forest conservation is hindering crop production which directly affects the provision of basic needs like food, clothing and home heating. There is the need for creating an enabling environment which will assist indigenes without making them become miserable such as; encouraging indigenes to carryout apicultural activities in and out of the forest, promote and encourage farmers to carry out agroforestry activities, as well as encouraging indigenes through financial aid to carry out small and medium size trade. This will help to boost their income and diversify their rural activities.

Keywords: Forest, conservation, Land use, change, livelihood, Sustainability.

Copyright @ 2020: This is an open-access article distributed under the terms of the Creative Commons Attribution license which permits unrestricted use, distribution, and reproduction in any medium for non-commercial use (NonCommercial, or CC-BY-NC) provided the original author and source are credited.

\section{INTRODUCTION}

Forest conservation has impacts on natural as well as human system especially agriculture. The putting in place of conservation policies requires the setting up of alternatives for livelihood sustainability so as to enable the indigenous population cope away from the conserved portion. Without this put in place, the indigenes will be left in the hands of hunger, misery and vice. Much paper work has been done in the form of laid down laws and policies, decrees have been signed on the issues of creating and managing protected areas in Cameroon for prosperity. There is need to move away from the paper work and rhetoric on providing alternative means of survival to adjacent population by making this option real. The creation of an enabling environment will gradually without violence make the adjacent population of the protected area to evacuate the area encroached upon and also take part in the process of conservation. Forest resources have been estimated to directly contribute to the livelihoods of 1.6 billion people worldwide [1]. They contribute to the livelihoods of some $90 \%$ of the 1.2 billion people living in extreme poverty, with an estimated $25 \%$ of the world's poor depending fully or partly on forest products for subsistence needs, and indirectly support the natural environment that nourishes agriculture and the food supplies of nearly half the population of the developing world countries [2].

Ngongbaa forest which is part of the Kilum mountain forest that belongs to the Nso clan has existed since time immemorial. This forest has been one of the major farm sites to Ngongbaa community and has long played a great role in terms of sustaining lives of the people as a source of water, food, medicine, fibres and cultural values. It has been estimated that close to $70 \%$ of Ngongbaa community depended on this forest for their livelihood [3]. When the worth of this forest became known to the population, each year, there were mass movements of people into the forest especially for agricultural purposes. This movement became exaggerated and started being manifested. This was due to the absence of sustainable management amongst 
actors. In 1987, Bird life started a project with its first priority to demarcate the forest beyond where no agricultural exploitation can take place. This was then followed by the promulgation of letter $n^{\circ}$ 594/MINAGRI/DAG/SREE of 10/4/1973 from the minister of agriculture on the total protection of Kilum mountain forest. This prohibited farming and grazing on all protected areas. This equally led to the conservation of Ngongbaa forest.

\section{RESEARCH METHODS}

\section{Location of study area}

Ngongbaa is a Clan in Kumbo Sub-Division of

Bui -Division in the North West Region of Cameroon (Figure 1). It is located between latitudes $6^{\circ} 141$ and $6^{\circ}$ $158 \mathrm{~N}$ and longitudes $10^{\circ} 311$ and $10^{\circ} 351 \mathrm{E}$ of the Equator. The study area covers a surface area of 3234ha and occupies the East, North-Eastern and South Eastern flanks of the Oku Mountain. Attitudinally the study area lies at approximately $2000 \mathrm{~m}$ above sea level.

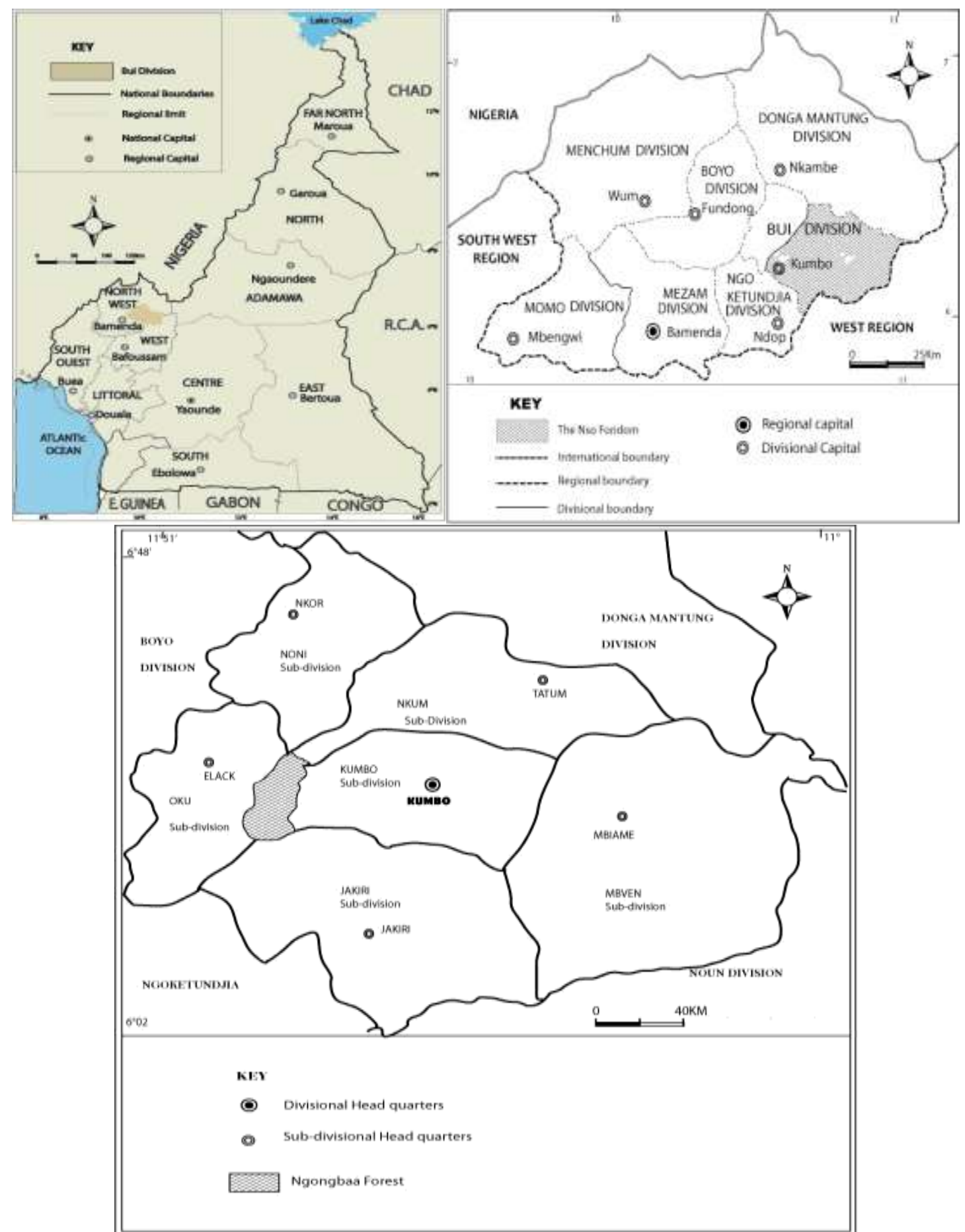

Fig-1: Location map of Ngongbaa in Bui- Division

Source: Adapted from the New Administrative map of Cameroon 


\section{MATERIALS AND METHODS}

Using mixed research approach, qualitative and quantitative data for this study was collected from actors of conservation, agriculturalist who have been taking part in agricultural activities in the forest, traditional authorities (farm landlords). The research tools employed were semi-structured questionnaires, indepth interviews and discussions in focus groups. Questionnaires were administered to 166 persons both agriculturalists and conservationists who have been resident in the study area for at least six months and above.

Table-1: Households respondents for 12 villages in the Ngongbaa community

\begin{tabular}{|l|l|l|l|}
\hline $\mathbf{N}^{\circ}$ & Name of village & Number of house hold 1987 & $\mathbf{9 \%}$ of 1987 household respondent \\
\hline 1 & Ntur & 38 & 3 \\
\hline 2 & Vekovi & 662 & 60 \\
\hline 3 & Wvem & 290 & 26 \\
\hline 4 & Taashem & 16 & 2 \\
\hline 5 & Shuukov & 16 & 1 \\
\hline 6 & Kai & 20 & 2 \\
\hline 7 & Fonmboh & 17 & 2 \\
\hline 8 & Tadu & 245 & 22 \\
\hline 9 & Simonkov & 145 & 14 \\
\hline 10 & Buh & 278 & 25 \\
\hline 11 & Mbontovi & 49 & 4 \\
\hline 12 & Mbonyar & 60 & 5 \\
\hline Total & 12 & 1835 & 166 \\
\hline
\end{tabular}

Source: National census (1987).

The aim of utilization of questionnaires in the study area was to exploit respondents' perception vis-àvis the change on agricultural land use in the Ngongbaa community. The sample size helped in calculating the number of questionnaires necessary for this write-up, was done using the total number of households for 1987. From table 1, the total number of households for 1987 was 1835. A sample proportion of $9 \%$ of the population was calculated for each village. A total of 11 focus group discussions were held. One multipurpose project in Vekovi, 2 traditional authority groups, (one in Wvem and the other in Vekovi), four groups of local grazers, three groups of farmers (women). These common group discussions enabled us to gather information from persons with a common interest fostered. In-depth interviews and focus group discussions were subjected to analysis.

\section{RESULTS AND DISCUSSION}

Migratory history from 1958 to 2018 as an indicator of land use change in the Ngongbaa Community

Migration refers to the movement of people from one place (point of origin) to another place (point of residence) [4]. Certain environmental conditions encourage movements of people and these movements in turn, can alter environmental conditions. In the field, reasons were advanced by the population table 2 concerning these movements in to study area. Some indigenes move into this forest in search of fertile soils of the forest, others moved due to lack of farmland meanwhile some moved because of witchcraft in their area of origin.

Table-2: Reasons given by the population for moving to Ngongbaa

\begin{tabular}{|c|c|c|c|c|c|}
\hline & & & Reasons & & \\
\hline No & $\begin{array}{l}\text { Surveyed } \\
\text { village }\end{array}$ & No of respondents & Fertile soils and its availability & Lack of farm land & Witchcraft \\
\hline 1 & Ntur & 2 & 1 & 1 & - \\
\hline 2 & Vekovi & 28 & 16 & 12 & - \\
\hline 3 & Wvem & 15 & 10 & 3 & - \\
\hline 4 & Taashem & 2 & 2 & - & - \\
\hline 5 & Shuukov & 1 & 1 & - & - \\
\hline 6 & Kai & 2 & 2 & - & - \\
\hline 7 & Fonmboh & 2 & 1 & 1 & - \\
\hline 8 & Tadu & 13 & 7 & 5 & \\
\hline 9 & Simonkov & 12 & 10 & 2 & 2 \\
\hline 10 & Buh & 17 & 9 & 7 & 1 \\
\hline 11 & Mbontovi & 3 & 2 & 1 & - \\
\hline 12 & Mbonyar & 4 & 4 & - & 1 \\
\hline Total & 12 & 101 & 65 & 32 & 4 \\
\hline Percentage (\%) & & 100 & 64 & 32 & 4 \\
\hline
\end{tabular}

Source: Field work (2019) 
The movements into Ngongbaa by local population led to emergence of villages described as mother, primary emerged villages, secondary emerged villages and prospective emerged villages as seen on table 5 and figure 12. It was found out in the field that the local population has been migrating from neighbouring mother villages at lower altitude to settle in in farmstead on the upper land as a means to reduce distance trekked to and from the farms. These farmsteads which usually grew in numbers as relations and friends joined their peers subsequently, became permanent residences and later became villages [5].
The effects of population increase on forest depleton and agricultural land use change in ngongbaa

Results on table 3 indicate that villages in Ngongbaa evolved periodically. Before 1958, there were four villages in Ngongbaa recognised as mother villages, meanwhile five villages were recognised between 1969/1987 (primary emerged villages) and in 1997 two villages surfaced as secondary emerged villages. Movements in to these villages as figure 12 illustrates were mainly from $\mathrm{Oku}$ and Nso according to field investigations.

Table-3: Emergence of villages in Ngongbaa area (1969-1987-2008)

\begin{tabular}{|l|l|l|l|l|l|l|}
\hline \multicolumn{2}{|l|}{ Mother Villages } & \multicolumn{2}{l|}{ Primary emerged villages } & Secondary emerged villages & $\begin{array}{l}\text { Prospective } \\
\text { emerged } \\
\text { villages }\end{array}$ \\
\hline Villages & $\begin{array}{l}\text { Recognised } \\
\text { period }\end{array}$ & Villages & $\begin{array}{l}\text { Recognised } \\
\text { period }\end{array}$ & Villages & $\begin{array}{l}\text { Recognised } \\
\text { period }\end{array}$ & \\
\hline Ntur & Before 1958 & Kai & 1969 & Mbontovi & 1997 & Taashem \\
Vekovi & Before 1958 & Mbonyar & 1969 & Fonmboh & 1997 & Shuukov \\
Wvem & Before 1958 & Simonkov & 1987 & & & \\
& & Tadu & 1987 & & & \\
& & Buh & 1987 & & & \\
\hline
\end{tabular}

Source: National censuses 1969, 1987, and 2008, Kilum- forest and field work 2019.

Some of these villages were named with respect to their physiognomy, or the first migrant in to this village. This is practical of villages such as 'Simonkov' and 'Shuukov'. 'Kov' refers to forest meanwhile Simon signifies the name of first inhabitant in this village. 'Shuu' on the other hand refers to mouth; therefore 'shuukov' means forest's mouth. In the 1940s, some names that villages/quarters bared suited perfectly with regard to their physionomy. In this rural mileu, most villagers/quarter names either begins or end with the appellation "kov"which literally signify an area of land that is naturally bushy with its vegetation comprising mostly of forest. The word "Kov" therefore means a bush/forest and some of these names includes;
"“Shuukov" meaning (at the mouth/entrance of the forest) "Vekovi"(in our forest), "Simonkov"'(the first inhabitant of that forest who was called Simon), Today these natural bushes/forests have all disappeared, meanwhile if these villages are to be renamed, one will realize that the word "kov" will not be reconsidered because their physiognomy has changed.

Land has been occupied either for settlement or agricultural use thus changing the face of these milieus. Due to migratory movements table 4 from mother villages at lower altitude as earlier seen to upper altitude, the population of this study area has evolved significantly between 1969 and 2008 .

Table-4: Population Evolution in Ngongbaa area (1969-1987-2008)

\begin{tabular}{|l|l|l|l|l|l|l|}
\hline No & $\begin{array}{l}\text { Name of the } \\
\text { Village }\end{array}$ & Pop 1969 & Pop 1987 & $\begin{array}{l}\text { House hold } \\
\mathbf{1 9 6 9 / 1 9 7 6}\end{array}$ & Household 1987 & $\begin{array}{l}\text { Projected pop } \\
\mathbf{2 0 0 8}\end{array}$ \\
\hline 1 & Ntur & 324 & 262 & 23 & 38 & 312 \\
\hline 2 & Vekovi & 3075 & 3833 & 662 & 662 & 4565 \\
\hline 3 & Wvem & 1443 & 1120 & 125 & 290 & 1334 \\
\hline 4 & Taashen & - & - & - & 16 & 202 \\
\hline 5 & Shuukov & - & - & - & 16 & 185 \\
\hline 6 & Kai & 107 & 200 & 13 & 20 & 238 \\
\hline 7 & Fonmboh & - & 64 & - & 17 & 76 \\
\hline 8 & Tadu & - & - & - & 245 & 2576 \\
\hline 9 & Simonkov & 1309 & 1868 & - & 145 & 2225 \\
\hline 10 & Buh & - & - & - & 278 & 2823 \\
\hline 11 & Mbontovi & & 60 & - & 49 & 95 \\
\hline 12 & Mbonyar & 410 & 476 & 33 & 60 & 567 \\
\hline & Total & 6668 & 7885 & 756 & 1836 & 15198 \\
\hline
\end{tabular}

Source: National censuses 1969, 1976 and 1987(Projections) 
The data on table 4 indicate that for 17 years (1969-1987) the population of Ngongbaa moved from 6668 to 7883 inhabitants, an increase of 1215 persons. Within the same period, the number of households moved from 756 to 1836 , signifying an increase of 1080 household. Given the fact that Ngongbaa is a rural milieu, such a significant increase in its population constituted a real menace to resources, particularly as such villages can be termed pre- modern subsistence societies, since they depend on the utilisation of natural resources at hand to acquire food, shelter, and clothing and to generate income for other basic needs. This pressure on land and forest resources can therefore be perceived at the level of emerging villages and household size figure 2 considering the fact that these indigenes moved into forest for agricultural activities.

In order to determine the influence of population increase on agricultural land use change, the migratory history of the indigenes were analysed. These movements were made known by the paramount Fon of Nso who is at the same time considered as the overall landlord. The various years were chosen from 1940 till 2011 to analyse these movements in this study area.

Table-5: The population responses on years of arrival in Ngongbaa forest

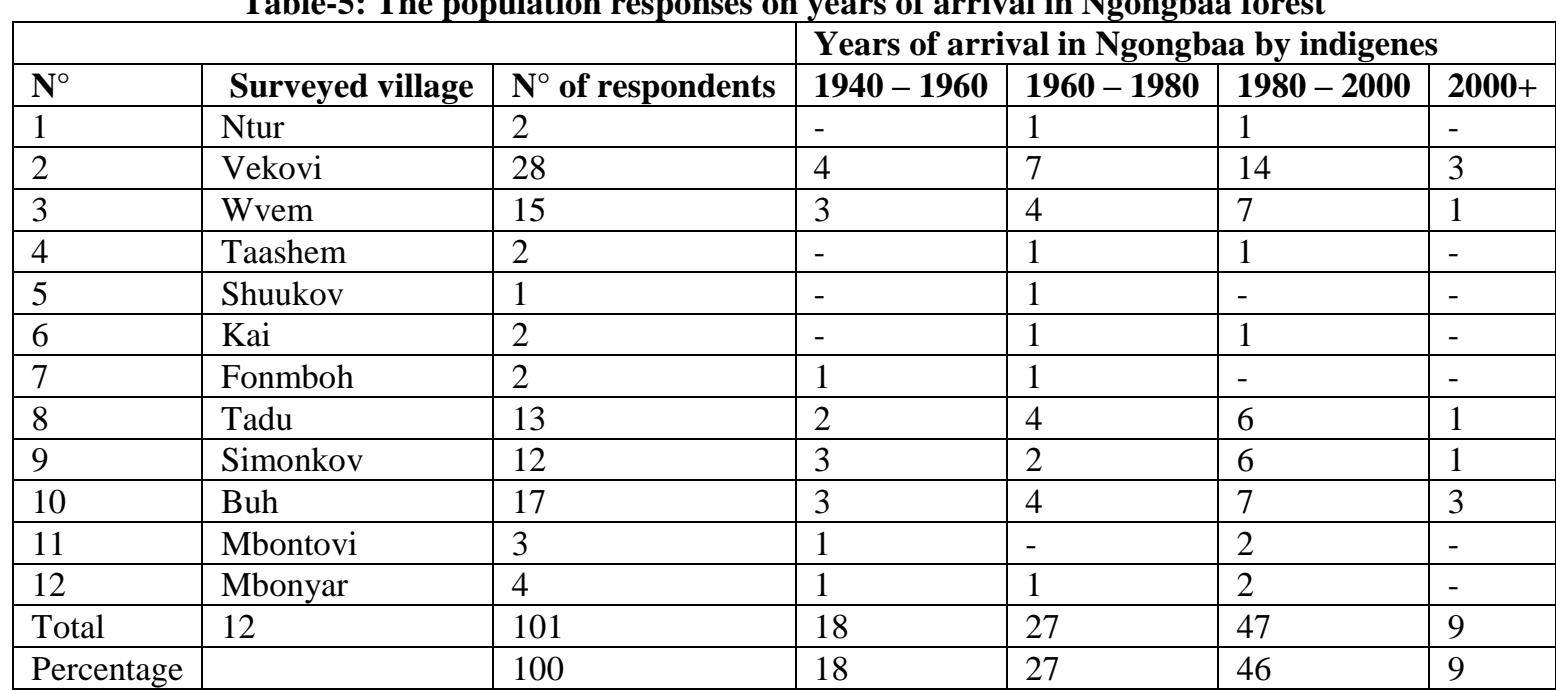

Source: Field work (2019)

From table 5, it can be seen that from $1940-$ $1960,18 \%$ of the population moved to Ngongbaa. $27 \%$ moved from 1960 - 1980 and from $1980-2000$, the number went up to $46 \%$. From 2000 and above, the numbers started dropping and from this period till present $9 \%$ of the respondent moved to Ngongbaa (Figure 2). This drop in movement equally signifies a drop in agricultural land acquisition. On figure three villages that are so close to the forest experiences a sharp drop than those further away from the forest. That is; villages so closed to the forest the movement is between 0-100 persons who move meanwhile villages further away receives more than 200 persons. This signifies a reduction in farmland availability in the conserved forest.

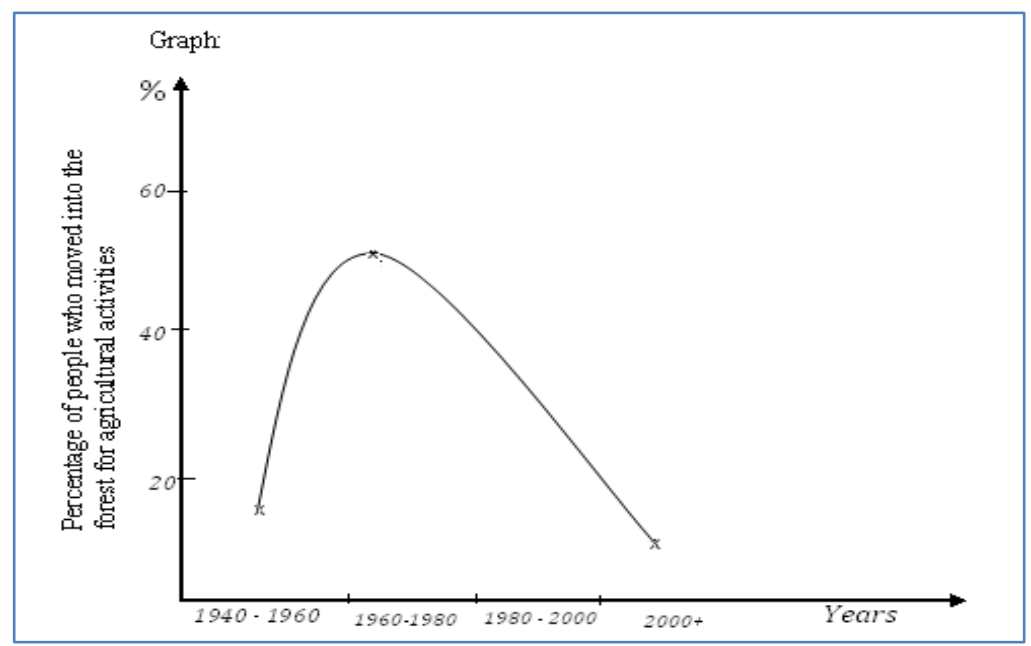

Fig-2: Graphical representation of indigene's years of arrival in Ngongbaa Source: Field work 2019 
This graph illustrates movement in to Ngongbaa either for agricultural activities or settlement purposes. It can be seen that the movement started in an increasing manner, attain its maximum in the $1980_{\mathrm{s}}$ and then started decreasing from 2000 till present. From table $4,64 \%$ of our respondent moved to Ngongbaa due to the fertile nature of soils and availability. The sharp fall on the graph indicate the absence of available farmland that formally acted as a source of attraction to the indigenes figure 2. The absence of these farms resulted from conservation policies implemented by Birdlife international in 1987 which checked further encroachment by agriculturalists.

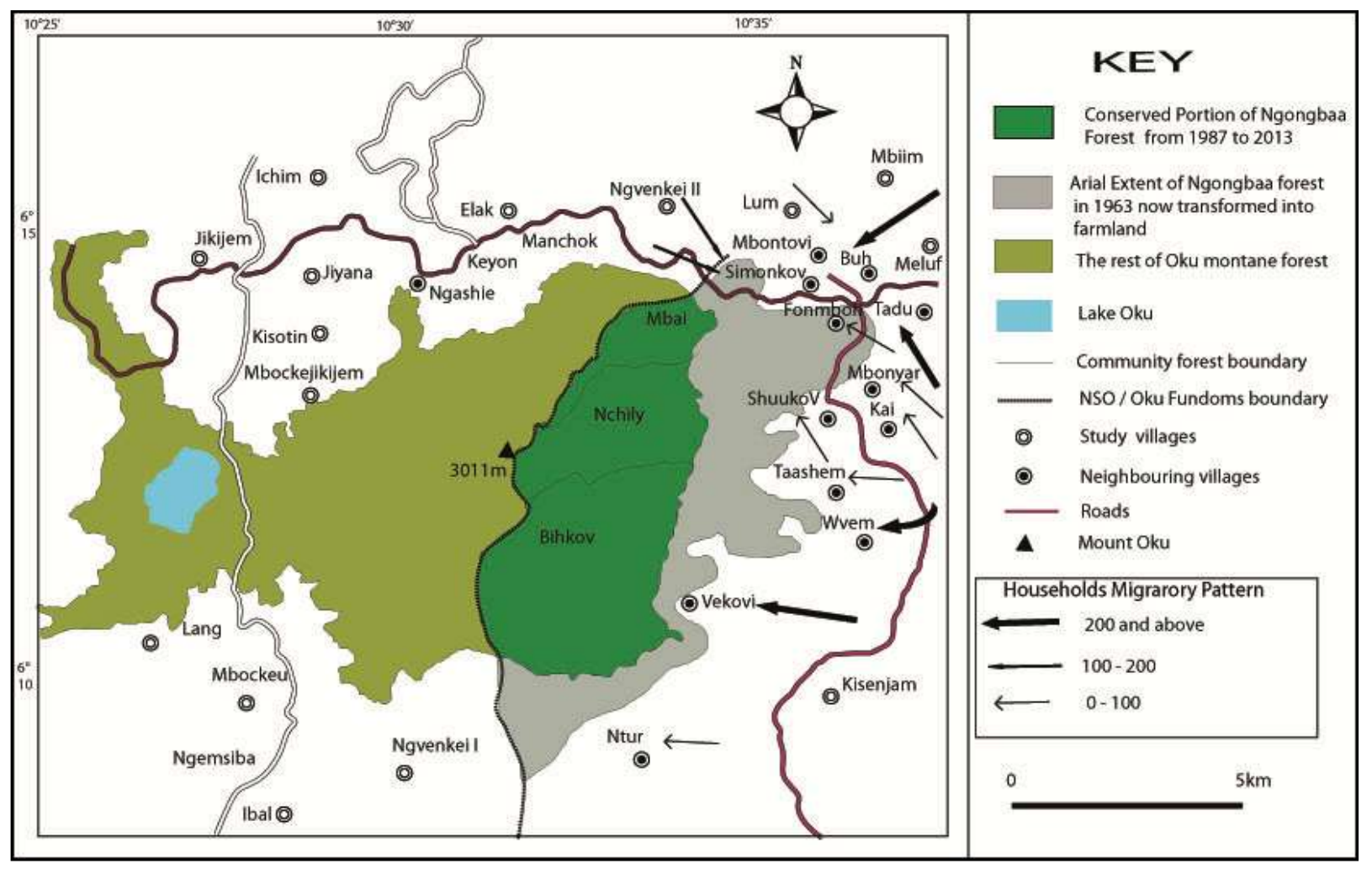

Fig-3: Migratory patterns in Ngongbaa

Suorce: Base Map of National Institute of Cartography: Nkambe 1/20000, National Censuses 1969, 1976 and 1987(Bucrep)

From independence in 1960, the Cameroon government took over management of forest. During this period, their forest was in the hands of the forestry service. The grip of the traditional authorities in the forest within this period was gradually dropping. The forestry service was to protect forest resource in order to ensure sustainable management of the forest. Studies revealed to us that in the long run, the interest of forestry service out - weighted that of the population [6]. In fact, they were just out to sale portions of the forest for their own personal interest. This contributed in further depletion of forest resources.

On the $22^{\text {nd }}$ May 1973, a unified forestry law in Cameroon was elaborated [7]. On the $4^{\text {th }}$ of August 1974 this forestry law was adopted which made the rights of indigenous population over land in British Cameroon recognized. This gave traditional authorities in Ngongbaa forest the rights to control and distribute land to their people. In the mid-1980s, the prices of coffee dropped in the international markets which according to investigations were the main source of revenue for the whole Ngongbaa community. There was then a rush to exploit the forest for agricultural purposes in order to improve their livelihood (cultivation of Irish potatoes, beans, goats, sheep, and cattle.) [8]. This period again witnesses mass movement in to forest for agricultural purposes by the Ngongbaa community.

In 1987, Bird life started a project known as the Kilum forest project with its major aim being conserving the habitat for two endemic birds known as turaco banamanni. The first priority of the project was to demarcate the forest beyond where no agricultural exploitation can take place. It should be mentioned here that this project took in to consideration a portion for agricultural activities. This was achieved through a participatory approach involving the local communities, the traditional authorities and the government of Cameroon while bird life acted as a facilitator. During the period of demarcation of the forest, various other measures were taken to conserve the habitation through prefectoral others such as; banning or prohibiting for instance farming, grazing and fires in the forest.). Bird life also went ahead to give their reasons for demarcating the forest which follows that forest is a major water shade providing water to 5 Divisions in Cameroon; Bui, Boyo, Ngoketunja, Noun and part of 
Nigeria. It was also important to conserve the forest as a catchments area. It was extrapolated that by 2005 , the full forest would have disappeared if these measures were not taken.Different strategies adopted therefore have helped to stop bush fires; there has been the undertaking of regular patrols on the forests and problems such as agricultural encroachment or illegal harvesting have been halted. This has assisted in forest regeneration. These regeneration strategies include:

\section{The ban on further encroachment for agricultural purposes}

The ban on further encroachment by farmers is one of the strategies used by actors to ensure forest regeneration. This Conservation effort made by land managers has helped to prevent further deforestation and has affected not only agrarian landscape but the population as well. It has helped this forest to regenerate meanwhile agriculturalists have been forced to concentrate only on forest farms thus influencing land scarcity in the forests. Before conservation efforts were made, the forest was fast depleting due to the potatoes innovation of the $1980 \mathrm{~s}$, but with the efforts of conservation (such as demarcating the forest) certain parts started regenerating. As far as Mbiame and the Dom forests, from 2005, forests have equally regenerated.

\section{The ban on Hunting}

In order to effectively conserve forests, the population has been prohibited from carrying out hunting activities in and around the forest. Anybody caught with hunting equipment or seen hunting in the forest is subjected under serious punishment. Following conservation norms, hunters have been banned from the forest. The reason given by actors is based on the argument that, animals in the forest helps to transport seeds which later on germinate thereby ensuring regeneration of the forest.

\section{No smoking in the forest}

Actors of conservation considers smoking as dangerous to the forest as such have placed a ban on smoking in and around the forest plate (1). To this effect therefore, anyone caught smoking around forest vicinities is subdued to serious sanctions. It is obvious that fire from cigarettes when dropped on dry grass/leaves can easily put the forest ablaze. To avoid such occasions the population is banned from smoking in and around the forest.

\section{Ban on bush burning in the forest}

The entire population has been prohibited from burning bushes in and around the forest. There has been a lot of sensitization against the ills of bush burning and the population is banned from this act. Winds are capable of transporting fires from one end to another. Statistics reveals that a majority of fire incidence in the conserved forest are caused by unknown sources. This ban is therefore to ensure proper conservation of forest resources.

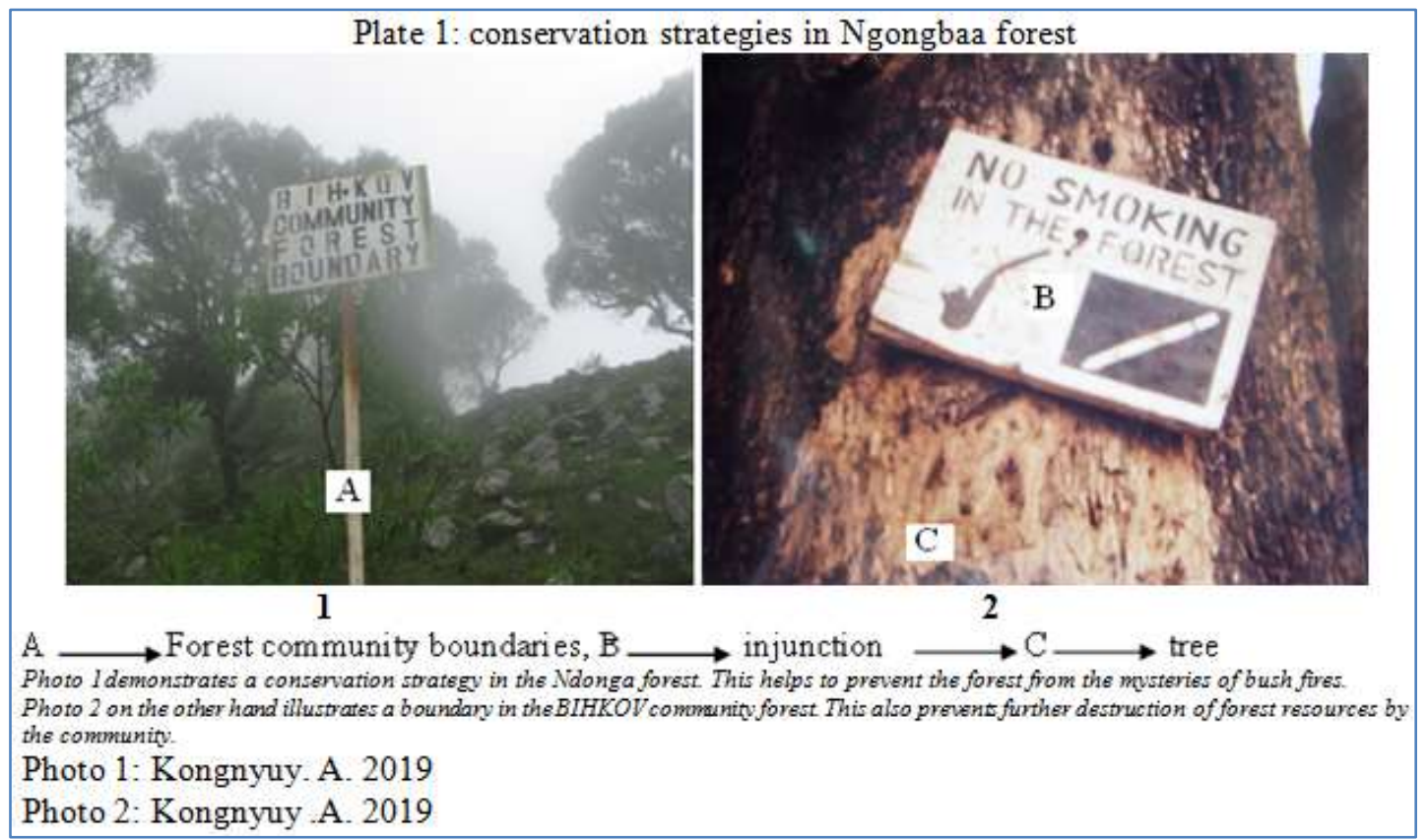




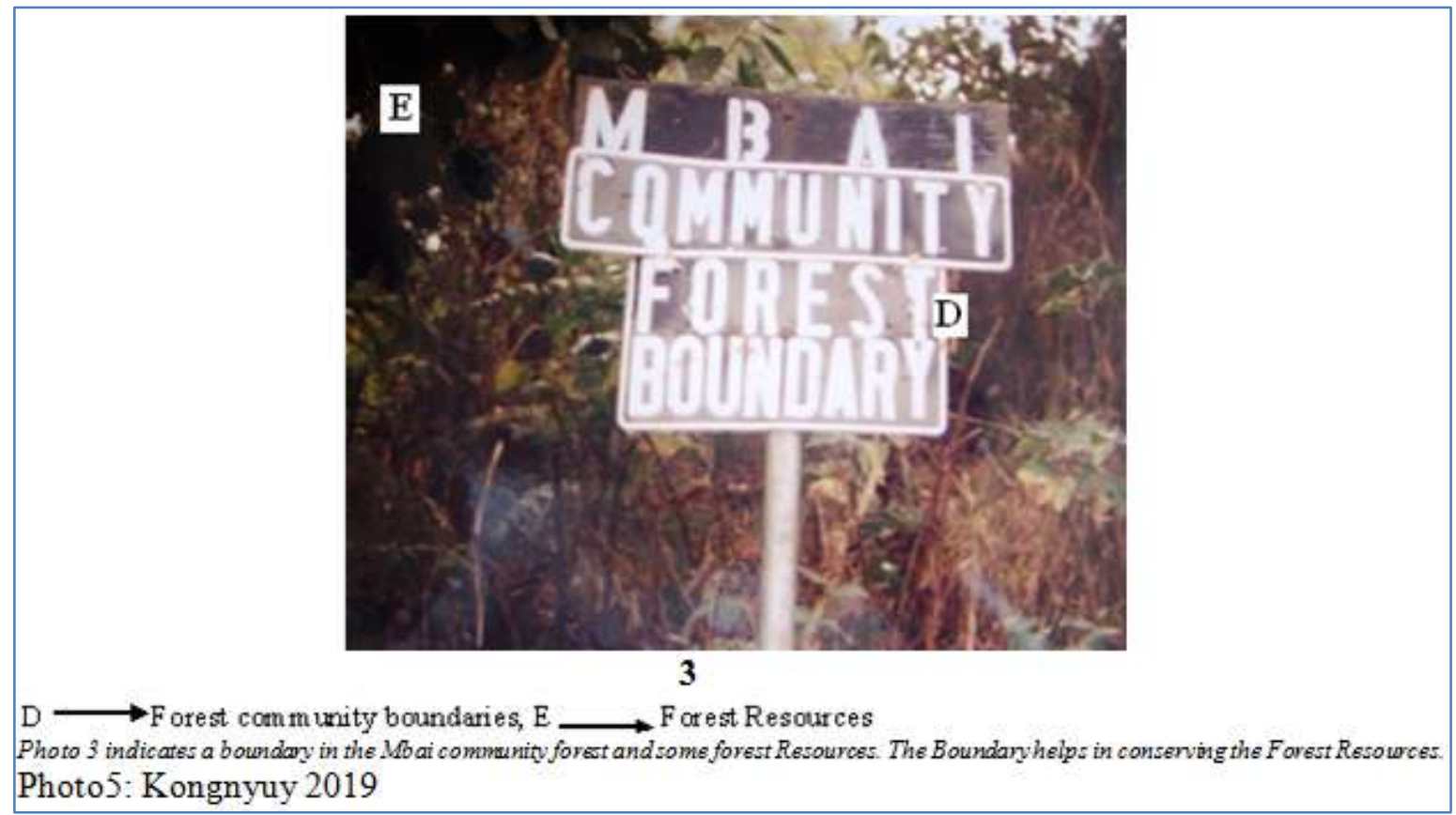

\section{Conserved animals as agents of regeneration}

With seeds and fruits produced by different tree species, animals in the forests act as agents of dispersion. According to informants in the field, conserved animals act as key elements of forest regeneration as they eat up seeds and fruits, move from one point to another while defecating. These seeds/fruits defecated by these animals later on germinate and grow up as young plants consequently ensuring forests regeneration. Animals conserved in the forest are therefore, considered vital in the process of conservation. Regeneration of the forest provokes change or transition from a degraded state into a regeneration state.

Conservation efforts made by actors of land management as seen above have helped to prevent further encroachment by indigenes. These efforts have an impact on resources and the population as well. It has helped this forest to regenerate meanwhile agriculturalists have been forced to concentrate only on forest farms thus influencing land scarcity in Ngongbaa. Before conservation efforts were made, the forest was fast depleting as seen on figure (4) due to the potatoes innovation of the 1980s, but with the efforts of conservation (such as demarcating the forest) certain parts started regenerating. These efforts added pressures on farmland since agriculturalists were bound to concentrate only on this portion of land. With conservation, land use has changed from agricultural land to a regenerated forest. Farmers are compelled to farm out of the forest which is challenging. This prevents them from providing their food needs. In most rural areas in Africa, Women carry about 75\% agricultural works and market up to $60 \%$ of the food [9]. Rural households living in forested areas in Africa and Asia derive over $20 \%$ of their income from forest. About $1 / 2$ the income from forest is non-cash and include; food, fodder, energy, medicine and household building materials [10].

There is an urgent need to conserve forest in an integrated manner taking into consideration the needs of the adjacent population. By examining all uses of land in an integrated manner, it makes it possible to minimize conflicts, to make the most efficient tradeoffs and to link social and economic development with environmental protection and enhancement; thus, helping to achieve the objectives of sustainable development [11]. If this alternative livelihood sustainably activities are not provided, the race of conservation will not be complete. 


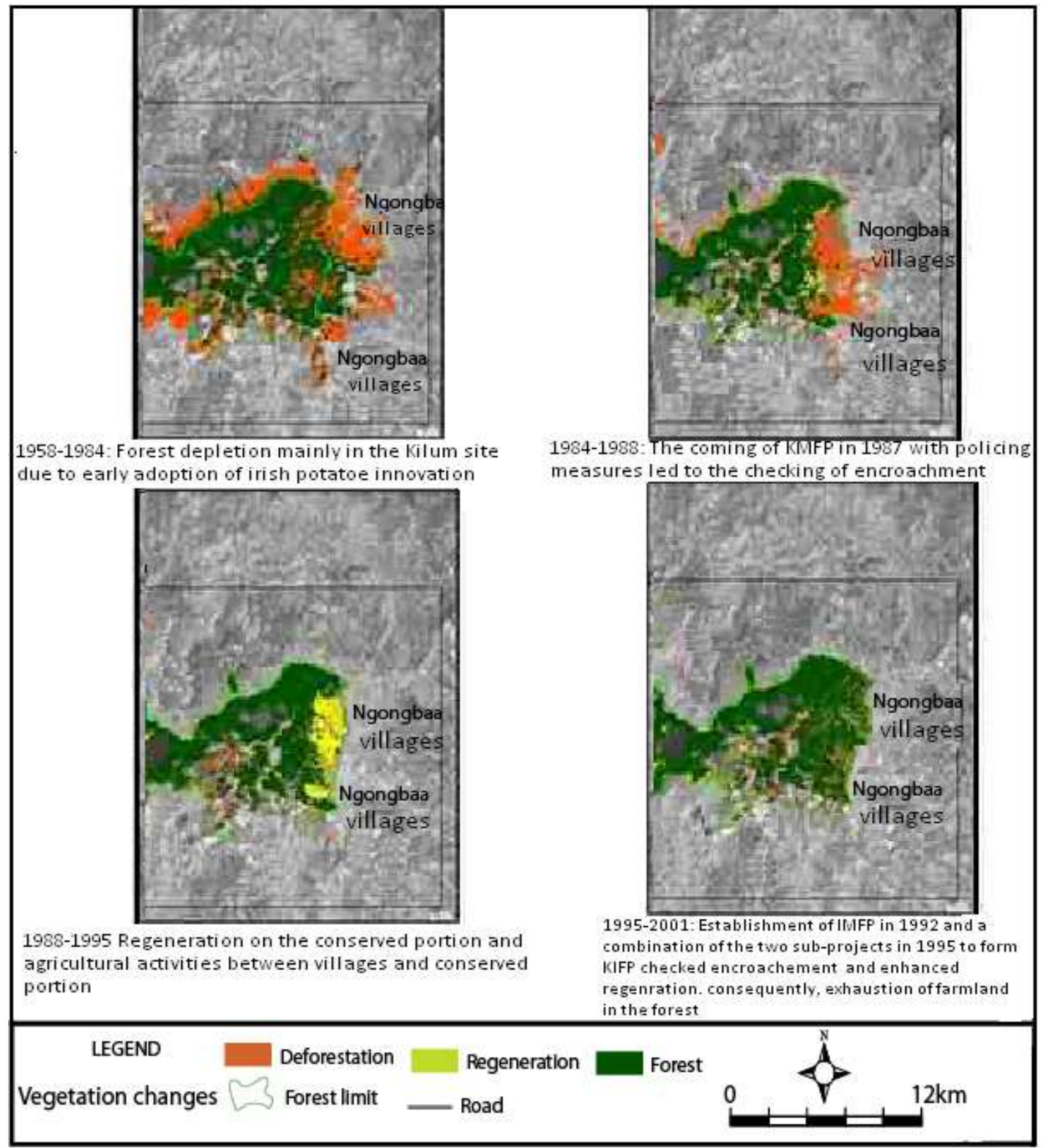

Fig-4: Forest Change over time due to Man's intervention and conservation efforts.

Source: GIS unit of the Royal Botanic Gardens, Kew, the Department of Geomatic Engineering of University College London and Lilum-Ijim Forest project, 2001 and adopted from Bachang

Figure 4 demonstrate land use resources in Ngongbaa such as forest. The state of this forest varies with different periods of time starting from1958 till 2001 and its variation can be explain from the point of view of human intervention either for deforestation purposes or conservation efforts made by actors of land management. From 1958-1984, no limits were set on this forest and agriculturalists entered in their numbers to cultivate Irish potatoes which led to the depletion of forest [12]. With the advent of conservation, agricultural land use has changed with negative impacts on crop production and subsequently population.

Due to forest conservation polices, hunting of conserved species has been banned. Monkeys eat up crops like maize, meanwhile rats consume other crops like potatoes, sweet potatoes, and birds on the other hand destroy maize, vegetables and beans during flowering period, consequently low output. This ban on hunting lead to a fall in the diet of indigenes as wild animals are a primary source of animal protein in diets of low income rural households. A ban on hunting affects their diets negatively.

Conservation has equally contributed to fall on income, for example; animal skin acts as a source of economic income. The skin is used in setting up cultural instruments like drums, caps why not walking sticks. The conservation of forests has influenced farmergrazier conflict in this study area. Farmer-grazier conflicts were identified in some parts of the forests and according to these farmers it contributes greatly to low output [13]. The farmer-grazier conflict is aggravated by the fact that the bororos refuse to compensate these 
farmers despite the long hours and efforts put in by farmers in cultivating. The issue of farmer-grazier conflicts is consistent especially around the conserved forest.
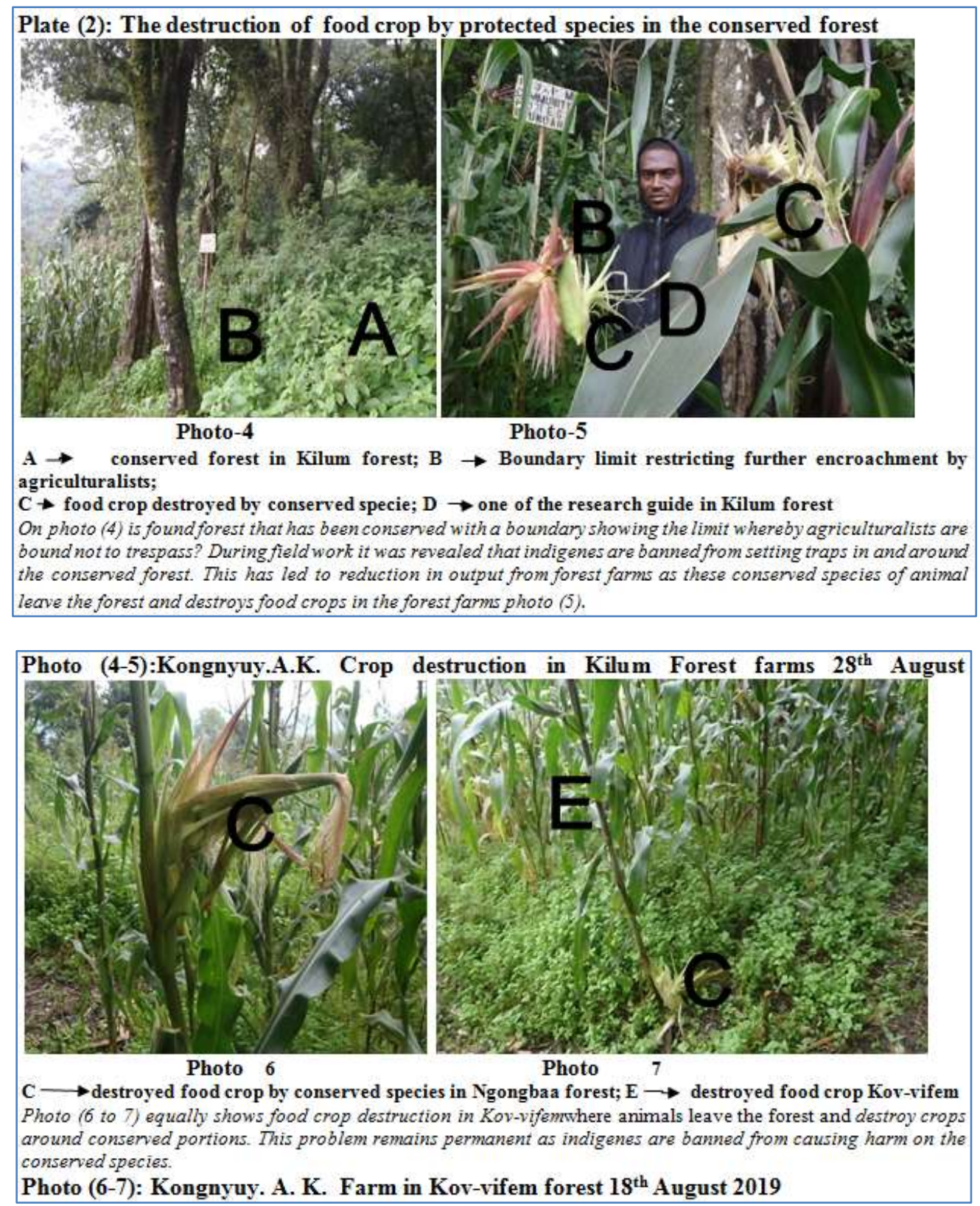

\section{DISCUSSION}

Given the fact that Ngongbaa is a rural milieu, life becomes difficult for indigenes when a land use such as forest is conserved without the putting in place of an enabling environment. According to field analysis, $80 \%$ of the rural population depend on wood for heating and more than $75 \%$ of its population consists of agriculturalists. The conservation of the forest implies the reduction in their source of income and subsequently nourishment. Equally, conservation of forest in the absence of the provision of life supporting activities makes the conservation efforts not fully achieved. Secondly it exposes the indigenes to that risk of hunger, misery and conflict. The suggestion of some alternatives for livelihood sustainability was seen as imperative;

\section{The encouragement of indigenes on apicultural activities}

Indigenes should be encouraged to carry out apicultural activities in and out of the forest. It was found out that, in this locality bees are considered as biological drivers of transformation in a conserved forest. Honey bee is described as biological agents of change because it plays a great role in forest regeneration. For specie (plant or animal) to survive, it must reproduce young ones. In flowering plants, the process starts with pollination which is the transfer of pollen from the anthers of the stemen to the stigma of a 
carpel. The major agents of pollination are: insects and wind. Bees set up the pace of fruit and seed formation (as they are involved in pollination process as seen above) through different plants in these conserved forests. They play a role in plant pollination and ensure the production of fruits and seeds. Honey bees account for $80 \%$ of all insect pollination. Bee pollination is essential for maintaining biodiversity. The main advantage here is that the community's ownership of bee hives in forest pushes them to protect their bee hives from bush fires and harm thereby preventing forest degradation and thus participating in forest management.

A majority of bee farmers gain a lot of money from this activity through the sale of products like honey which is in high demand. The high demand is due to its high quality and good taste, which is loved and admired by all. Bee farming gives community members a source of livelihood from the sale of honey and makes them see the importance to protect the forest. Apart from commercial purposes, honey bee serve as a source of food and medicine.

Bee keeping in the forest helped to remove the eye of indigenes as harvesting of different products from this activity makes them not to feel cheated or may be exempted from enjoying forest resources.

\section{Encouraging indigenes to carry out agroforestry practices}

The population of Ngongbaa is so attached to trees in general as they depend on them for wood, planks, fruits, medicine. Forest conservation prevents the entire population from providing these basic needs. The adoption of agroforestry practices enables them to provide subsistent needs such as food, energy supply and construction. Through the sale of wood from agroforestry, the income of the farmer is boosted. Apart from basic needs, agroforestry provide ecological needs through practices such as windbreaks, contour bund, alley cropping and fire breaks which helps in improving agricultural land use away from the conserved forest.

\section{Enabling indigenes to diversify rural activities}

This can be done when the main actors of forest conservation take upon themselves and train indigenes on other income generating activities that are not agriculturally incline. This could be activities such as fabrication of detergents locally, training them on trade like embroidery shoe mending etc. This can help indigenes raise income even better than agricultural activities.

\section{CONCLUSION}

The Ngongbaa man's life is centered on forest and its resources, as men and women carryout daily activities in order to provide for their needs. It has been estimated that close to 300 people live within a day's walk to the forest. The inability of conservators to provide alternative income generating activities that could derail the attention of local people from the forests made conservation efforts from the beginning a failure. These farmers though respecting the rules of conservation carry out such acts at their detriment as a majority of them are unable to find new farm land out of the forest. A hand fold of these farmers out of their desperateness move to different villages searching for new farm lands. They encounter challenges such as renting of new farm lands which are very costly, high cost of production and transportation, abandonment of families, lack of money to rent farms. Conservation of a resource without the creation of an enabling environment is doomed to fail.

\section{REFFERNCE}

1. World Bank. (2003). Reaching the poor: a renewable strategy for development. World Bank, Washington D.C. 166

2. World Bank. (2004). From slash and burn to replanting: Green revolution in the Indonesian uplands-World Bank, Washington D.C. 341

3. Kongnyuy. A. K. (2014). Agricultural Land use change and conservation effort in Ngongbaa, BuiDivision, North West Region-Cameroon 150p

4. Charlse, W. H. (1986). Elements of human geography, Unwin hyman limited, 15-17 Broad wick street London WIV IFP. 135-160

5. Enchaw, B. (2009). An assessment of conservation strategies in the management of natural resources in Kilum -Ijim forest DEA in Geography, Yaounde, 1. 177

6. Bird Life International; Minef. (2002). Kilum-Ijim: Annual report January -December 2002, 34.

7. Tatah, L. B. (2010). Impact of Cameroon's forest policy on the indigenous management in the Ngongbaa forest area, Nso ,Bui-Division, 72

8. Macleod, H. (1986).Conservation of Oku mountain forest, Cameroon ICBP study report N0 15 , Cambridge, 20.

9. World Bank. (1992). Trends in Agricultural diversification: Regional perspective. World Bank Washington D.C. 207

10. Paola, A. (2017). Landscape degradation: a world of landscape restoration opportunities. Atlas of sustainable Development goals, 3 .

11. Mbenkum, F.T., Fisiy, F.C. (1992). Ethnobotanical survey of Kilum mountain forest Cameroon. Project report Series No.1 Jan 19911992.IUCN/WWF.

12. Kah, E. (2004). Farmer- grazier conflict in BuiDivision. Maitrise dissertation, University of Yaounde I, 144.

13. Wirsiy, E. (2014). Training manual on Agroforestry practices in coffee farms in OkuCameroon, 18. 